\title{
IMPUGNACION Y SUSPENSION DE ACUERDOS DE LAS CORPORACIONES POR INFRACCION DE LAS LEYES
}

\author{
por \\ Angel Martín del Burgo y Marchán
}

SUMARIO: I. ADVERTENCIA PRELIMINAR.-II. CONSIDERACIONES GENERALES.-III. ESTUDIO ANALITICO DE LA INSTITUCION: 1. NATURALEZA JURf́lCA. 2. ENTES Y ORGANOS a lOS QUE SE ATribuye ESTa legitimación: a) Del Estado. b) De las Comunidades Autónomas. c) De las Corporaciones locales. 3. EL PROCESO PROMOVIDO POR ESTE TIPO DE IMPUGNACIONES. 4. ACTOS IMPUGNABLES: a) Que se trate de actos o acuerdos. b) Que se trate de auténticos actos administrativos. c) Que emanen de una Corporación local. 5. FUNDAMENTO DEL ACUERDO IMPUGNATORIO. 6. FACILITACIÓN DEL PROCESO. 7. PROCEdIMIENTO PROCESAL: a) Inicio. b) Tramitación. c) Sentencia. d) Recursos.

\section{ADVERTENCIA PRELIMINAR}

Con el fin de ofrecer una exposición más nítida del tema que nos ha sido asignado, centramos el mismo dentro de la visión general que el propio legislador nos ofrece, al regularlo en el artículo 118 de nuestra Ley Jurisdiccional, y en la reforma efectuada en recientes disposiciones legales, a las que nos referiremos más adelante. Por eso, conscientemente, y para evitarnos digresiones perturbadoras, nuestro discurso será lineal, eliminando del mismo toda refe- 
rencia a puntos tangenciales, como serían los tratados en los artículos 186 y 224 de la vigente Ley del Suelo, Texto Refundido de 9 de abril de 1976, sobre suspensión de licencias urbanísticas y órdenes de ejecución en materia urbanística, cuyo contenido constituya una infracción urbanística grave, o suspensión de acuerdos municipales que constituyan infracción manifiesta de normas urbanísticas.

\section{CONSIDERACIONES GENERALES}

Creo que fue Savigny el autor de esta definición del Derecho: "es la vida misma del hombre contemplada desde un aspecto determinado". Confieso que cuando leí esto -no recuerdo dónde ni cuándo- quedé altamente impresionado, llegando a pensar que la frase me introducía en la verdadera entraña de lo jurídico.

Sin embargo, precisamente en el momento en que acometo el presente ensayo, la frase me viene a las mientes, pero no para acatarla en postura sumisa y devota, sino para analizarla críticamente, llegando a la conclusión, tras de esta nueva postura, que la misma contiene una parte de verdad incuestionable: "El Derecho es la vida misma del hombre», seguida de otra un tanto discutible: "...contemplada desde un aspecto determinado".

$\mathrm{Y}$ no es que considere, con lo dicho, que el Derecho ha de contemplar la vida del hombre en todos sus aspectos, lo que es impropio de todo quehacer científico o técnico, sino que el mismo, y en concreto la institución objeto de nuestra exposición, son difícilmente comprensibles y explicables, si se les analiza desde un solo punto de vista: desde el superficial de su estructura jurídica, esto es, desde su pura juridicidad, tecnificada y especializada.

Sólo saliéndose previamente del campo acotado por la técnica jurídica específica —en nuestro caso, la procesal administrativay contemplando el fenómeno desde perspectivas más amplias y más profundas, podrán captarse los problemas implicados en este tema. Quiero decir con esto que, para la mejor comprensión del fenómeno, y para contar con unos principios que a la hora de interpretar y aplicar la normativa que lo regula han de resultar tan fecundos y útiles, resulta muy conveniente esa salida, efectuando incursiones por los campos reservados al Derecho político y al constitucional.

No creo que este enfoque de la cuestión represente un atentado a los cánones de la metodología científica, incluso dentro de la laxitud con que ésta ha de ser administrada en una ciencia social, cul- 
tural o humana, como es el Derecho, esto es, en una disciplina cuya cientificidad ha sido puesta en cuarentena por los propios juristas (1). $Y$ no lo creemos porque, en realidad, no pretendemos hacer otra cosa que poner en relación esta figura, configurada por el Derecho procesal y por el administrativo, con las causas que la motivan, y los fines que con ella se pretenden, incubadas aquéllas y éstos en esas otras áreas del Derecho político y constitucional. Se trata, pues, de poner en juego una relación interdisciplinar, pero entre disciplinas de un tronco común: el jurídico. Un recurso que preserva las exigencias de toda ciencia fundada en la abstracción, esto es, en el recorte de perspectivas y observaciones, en cuanto ninguna tiene capacidad para abarcar la totalidad de una cosa. Recordemos, a este respecto, que Georg Simmel (2) nos tiene dicho que: "Ante la totalidad de la cosa y de las cosas, crece cada ciencia por división de aquella totalidad en diversas cualidades y funciones, una vez que se ha hallado el concepto que separa estas últimas, y permite comprobar metódicamente su presencia en las cosas reales».

Así, pues, sin necesidad de renegar de la ortodoxia científica, y sólo con el simple procedimiento de conectar el Derecho administrativo y procesal con el político y el constitucional, es bastante para que situemos a la institución en examen no sólo dentro de su campo funcional y operativo, sino en el estructural de la organización del Estado, y para que juzguemos adecuadamente el porqué de su existencia, así como los objetivos a cumplir por ella.

Partiendo de este enfoque metodológico, nos damos fácilmente cuenta que los acuerdos de suspensión e impugnación de actos de las Corporaciones locales ponen en tensión la relación entre las mismas y el Poder central; relación que, como agudamente han señalado Bryan KeIT H-Lucas y Peter G. RICHaRdS (3), constituye uno de los motivos de mayor influencia en la conformación de la naturaleza de cualquier sistema de gobernación local.

Al emplear el término "relación» para expresar el enlace existente entre los Entes locales y el Estado, lo hacemos en el sentido vulgar del mismo, y un tanto forzados por la pobreza de la terminología jurídica. Decimos esto porque el engarce entre unos y otro no es el propio del que en la teoría general del Derecho se califica

(1) J. H. KirchmanN: La jurisprudencia no es ciencia, Instituto de Estudios Políticos, Madrid, 1949.

(2) Georg Simmel: Sociología, Bibl. Rev. Occidente, Madrid, 1977, vol. I, pág. 14.

(3) Bryan Keith lucas y Peter G. Richards: Historia del Régimen local inglés en el siglo XX, Instituto de Estudios de Administración Local, Madrid, 1980, pág. 241. 
de "relación jurídica». En ésta, como tan ingeniosamente ha expuesto el genial Carnelutti (4), se destacan no tanto las cosas (los sujetos o los objetos), sino lo que hay entre ellas. Aunque la apariencia, viene a decir, es que entre las mismas no existe nada, sino el vacío, una distancia. Distancia que, en principio, representa una separación. Separación que en Derecho privado, apostillamos por nuestra parte, es perfectamente coherente con la posición de las personas - privadas- que en él ejercen el protagonismo, las que en ese campo, dentro de lo que cabe, pueden ser presentadas como independientes.

Los Entes locales, por el contrario, respecto del Estado del que forman parte, no se encuentran con él en una situación semejante. Por eso suele excluirse el término "relación jurídica», siendo corriente expresar la idea con un vocablo un tanto impreciso: "articulación", con un designio matizador, aprovechando que el mismo no forma parte del "cliché» terminológico de la teoría general civilística.

Los Entes locales y el Estado están forzosamente integrados por la situación especial existente entre ellos. El territorio de aquéllos es territorio del Estado. La población de aquéllos es población del Estado también. El Estado no cuenta ni con un solo palmo de terreno que, a la vez, no forme parte de un término municipal. Interesante resulta recordar en este punto la doctrina sentada por la Sala de lo Contencioso de la Audiencia Territorial de Pamplona, en su sentencia de 19 de octubre de 1965, ponencia de Pablo Garcf́a Manzano, ampliamente recogida por Nemesio RodRíguez MORO (5), a propósito de uno de los muchos conflictos surgidos sobre competencias en zona marítimo-terrestre; doctrina que viene a puntualizar la imposibilidad de poder considerar dividido el territorio nacional en términos municipales, por una parte, y en territorios o bienes de dominio público, por otra; entre otros motivos, porque el dominio público está concebido en el Derecho positivo no como una relación de poder, sino como una relación de propiedad.

La ley física de la impenetrabilidad de los cuerpos no rige, pues, en el ámbito jurídico. El Derecho construye su propio mundo, lo que le permite, sobre un mismo sustrato material —un determinado

(4) F. CARnelutti: Teoría general del Derecho, Ed. Rev. Derecho Privado, Madrid, 1955, pág. 183.

(5) Nemesio ROdríguez MORo: «Las diversas competencias que concurren en la zona marítimo-terrestre», en Rev. Adm. Pública, núm. 52, enero-abril 1967, páginas 281 y ss. 
territorio-, hacer aparecer una diversidad de sujetos: el Municipio, la Provincia, la Comunidad Autónoma, el Estado.

Entre ellos, más que una cadena, lo que se forma es una pirámide, por superposición de estratos organizativos, lo que ha permitido a algún autor, como a nuestro Adolfo PosADA (6) hablar de «la penetrabilidad psicológica de las personas sociales".

Este poder constructor del Derecho es el que puede explicar la paradoja de que un mismo autor pueda decir, en un determinado pasaje de su obra, que detrás del mandatario de Derecho privado se encuentra otra persona, mientras que «detrás de los órganos del Estado no existe nadie», y en otro, no tenga inconveniente en afirmar que «todas las unidades que el Derecho eleva a la categoría de sujetos tienen existencia real» (7).

Sin entrar ahora en el inextricable problema sobre lo que hay de realidad o de ficción en las personas jurídicas, $y$, concretamente, en las de Derecho público, lo cierto es que en ellas hay de ambas cosas. Empero, cualquiera que sea la verdadera naturaleza de las mismas, lo que importa, en nuestro empeño, es que los distintos Entes, cubiertos por una misma soberanía, y calificados de territoriales, se encuentran forzosamente condenados a convivir entre sí, y a convivir con el Estado del que forman parte, y todos, con relación a éste, cualquiera que sea el régimen político imperante, en una situación de cierta subordinación (8). Cosa que nada tiene de sorprendente, puesto que se parte de ese elemento común: el espacio, y éste fue considerado en cierta ocasión por KANT como «la posibilidad de la coexistencia».

Ahora bien, fijaos que KaNT sólo ve en el espacio una "posibilidad" de coexistencia, de coexistencia no conflictiva se sobreentiende, ya que el espacio puede ser, como de hecho lo ha sido a lo largo de la historia, factor determinante de innumerables pugnas y luchas, desde las rivalidades pueblerinas a conflictos bélicos de alcance mundial, como la guerra emprendida por Hitler por el «espacio vital» para su pueblo.

Dentro de un mismo Estado, los problemas graves que a éste

(6) Adolfo Posada: «Base física del Estado», trabajo incluido en el libro Escritos municipalistas y de la Vida local, Instituto de Estudios de Administración Local, Madrid, 1979, pág. 141.

(7) Georg JellineK: Sistema de los derechos públicos subjetivos, citado por Herman Heller en su libro La soberanía, México, 1965, págs. 146-147.

(8) Herman Heller, en su citada obra, aun refiriéndose a las relaciones internacionales de los Estados, expresa la idea general de que el Derecho «provoca la formación de relaciones de subordinación». 
se le suelen presentar no son los provenientes del enfrentamiento con el súbdito, por más que no hayan faltado autores que hayan teorizado sobre una confrontación entre ambos, como ocurre con Herbert SPENCER en su libro The man versus the State, sino precisamente los relacionados con sus Entidades territoriales, centrados en la autonomía de las mismas.

En este punto, vamos a descender al tema concreto que nos ocupa, aunque sin entrar de lleno todavía en el mismo, anticipando lo que él representa como síndrome de lo que se ha venido considerando como intervención atentatoria de la autonomía de los Entes locales; así, ni más ni menos.

Por de pronto, vamos a decir una cosa: si las estadísticas judiciales fueran lo completas que debían ser, no dudamos en afirmar que éstas nos demostrarían: $1 .^{\circ}$, que los acuerdos de la Administración del Estado, de suspensión e impugnación de los de los Ayuntamientos, se producen muy espaciosamente, y en proporciones ínfimas, si se relacionan con el número de Municipios existentes, y con la continua emisión de actos por parte de éstos; $2^{\circ}$, que, por lo que se refiere a las Provincias, habrá que buscar con lupa los casos en que este evento se haya producido, dando motivo al inicio de la fase procesal, regulada en el artículo 118 de nuestra Ley Jurisdiccional.

¿Qué nos revela este dato?: nos revela la desproporción entre la importancia que se ha concedido al uso de esta medida por parte de la Administración del Estado y la mínima incidencia que en la vida real ha tenido y viene teniendo, ya que de destacar algo, tendría que ser los muchos actos ilegales que, sin duda, tendrán que existir (perdón al principio de legitimidad del acto) y que no son suspendidos ni impugnados por la Administración central. Como igualmente nos evidencia la diferencia de resultados entre actos de los Ayuntamientos y los de las Diputaciones Provinciales. Diferencia que por ser constante y no coyuntural, no se puede atribuir al azar, sino a la distinta naturaleza y talante de unas y otras Entidades, y al distinto trato que con ellas el Estado tiene.

Distinción de naturaleza que, un tanto ortopédicamente, se ha intentado corregir, sobre todo a partir de la Ley de Bases de Régimen local de 17 de julio de 1945, y de su Texto Articulado de 16 de diciembre de 1950, presentando un ordenamiento común, que en nuestra Patria tiene algún que otro antecedente, pero siempre aislado, si se compara con los proyectos y los textos legales que han 
venido proyectando o regulando el régimen jurídico de Ayuntamientos y Diputaciones Provinciales por separado; entre los proyectos: los de Maura de 1903 y Maura-Cierva de 1907; entre los textos legales: el Real Decreto de 23 de julio de 1835; la Ley de 15 de octubre de 1836, que restableció la de 3 de febrero de 1823; la de 8 de enero de 1845; la de 20 de agosto de 1870, reformada por la de 16 de diciembre de 1876, y, por fin, la de 2 de octubre de 1877, vigente hasta la entrada en vigor del Estatuto municipal de Calvo Sotelo de 1924, más la Ley municipal de 31 de octubre de 1935, todos ellos referidos en exclusiva a los Municipios. Y por lo que se refiere a las Provincias, ya anunciada su creación en el Decreto de las Cortes de Cádiz de 23 de mayo de 1912, habrá que citar el Real Decreto de 30 de noviembre de 1833, la Ley de 29 de agosto de 1882 y el Estatuto provincial de 1925, también de Calvo Sotelo.

Mas lo relevante no es que exista o no deba existir un ordenamiento común del régimen jurídico de Ayuntamientos y Diputaciones Provinciales, sino el hecho, contrastado por la realidad, de que estas últimas, en esta materia, como en tantas otras, no presentan problemas al Estado o el Estado no se los plantea a ellas. Son paradojas de la vida. El Municipio, con todo el carácter natural que se le atribuye (9), ha venido siendo problemático, mientras que la Provincia, producto del arbitrio y artificio del legislador y del gobernante (10), nos muestra una existencia sosegada y apacible, sólo alterada en estos momentos por quienes pretenden, o han pretendido, negar su propia existencia, al intentar una nueva división administrativa, basada en la comarcalización del territorio, como es el caso de Cataluña.

(9) Existe en todo Municipio la conjunción de dos elementos que no pueden ser más naturales: la población municipal, agrupada por razón de vecindad, y un territorio sobre el que aquélla se asienta. Sin embargo, tanto porque ello no es óbice para la acción del Estado, y de los propios Municipios, en la creación, alteración, fusión o traslado incluso de poblaciones, como por el mal ejemplo dado por quienes no tienen reparos en calificarlos de entidades naturales para luego, a la hora de la verdad, cercenar en grado máximo su autonomía, lo cierto es que son muchos los autores que procuran eludir tal calificativo, como ocurre con Rafael ENTRENA CUESTA, al definirlo como «Ente público menor territorial primario» en su Curso de Derecho administrativo, 5. edición, Madrid, 1974, tomo I, pág. 277.

(10) «Con independencia de antecedentes en el doceañismo de Cádiz y en su resurrección en el trienio $1820-1823$, la división provincial española es la obra personal de una de las figuras más grandes, y quizá más olvidadas, de nuestro siglo xIx: el granadino Javier DE BURGos. Es el Decreto de 30 de noviembre de 1833, suscrito por este gran creador, el que acertó a establecer definitivamente la división provincial sobre la que todavía hoy vivimos, modificada sólo en 1925, en cuanto a la división en dos Provincias de las Islas Canarias» (Eduardo García DE EnTERría: Problemas actuales del Régimen local, Universidad de Sevilla, 1958, pág. 13). 
Pero existe otra paradoja aún mayor: por un lado, se acumulan alabanzas por los juristas a todo lo que represente una medida de fiscalización de la actuación administrativa, pero, por otro, se critican aquellas que supongan lo que consideran un atentado a los principios autonomistas de las Entidades territoriales. ¿En qué quedamos? ¿No están todas las Entidades, desde el Estado al Municipio más pequeño, al servicio del individuo, cualquiera que sea la teoría política que se profese - personalista o transpersonalista-? ¿No es el individuo el destinatario último de todo sistema de libertades? Entonces, ¿ ¿no resulta anacrónico ese «sentimentalismo trasnochado defensor a ultranza de la autonomía local?», como nos viene a decir José María Boquera Oliver (11).

Quiero salir al frente del estupor que pueda provocar esta osadía mía, que hasta podrá ser considerada como delirante. ¡Reproducir ahora -en 1983- lo que dijo el profesor BoQUERA en 1961! ¡Calificar el autonomismo local de sentimentalismo trasnochado, en plena fiebre autonomista! Me atrevo a ello porque, como demócrata, no soy precisamente un parvenu. Y porque, por lo mismo, no pretendo revivir un espíritu definitivamente enterrado. Pero lo cortés no quita lo valiente. La irrupción volcánica autonomista, como reacción a una situación de autoritarismo y de centralismo exacerbado, era inevitable, pero los juristas estamos obligados a no ser arrastrados por la vorágine de los acontecimientos. Cierto que, como ha dicho Ralf DAHRENDORF (12), "los temas importantes en la historia no están unidos por una línea recta, ni por el modelo del salto dialéctico del caballo, ni tampoco por ninguna lógica rígida de desarrollo", mas los juristas podemos contribuir muy positivamente a que esa línea recta no se rompa más de lo debido; a que los corsi y ricorsi de la historia, a que se refirió J. B. VIco, o los ciclos históricos estudiados por Oswald SPENGLER, continuando a HEGEL y prefigurando a ToymBEE, no impliquen, en uno de sus bandazos, una catástrofe para todos. Es mejor que esto lo hagamos nosotros a que lo hagan otros, incluso para bien de esos otros (13).

De todas formas, resulta innecesario parapetarse en una visión catastrofista para justificar el mantenimiento, y hasta el reforza-

(11) José María Boquera Oliver: «La facultad gubernativa de suspensión e impugnación de acuerdos locales manifiestamente ilegales», en Rev. Adm. Pública, número 36, septiembre-diciembre 1961, pág. 127.

(12) Ralf DAHRENDORF: Lebenschancen, Oportunidades vitales, en la traducción española, editada por Espasa-Calpe, Madrid, 1983, pág. 161.

(13) Denis DE Rougemont: Tres milenios de Europa, Ed. Revista de Occidente, Madrid, 1963, pág. 313. 
miento, de la institución de que se trata, porque, como más adelante veremos con más atención, la misma no implica más que la concesión de una legitimación para poder residenciar jurisdiccionalmente determinados actos de las Entidades locales, siendo los Tribunales los encargados de pronunciarse soberanamente sobre la legalidad o ilegalidad de los mismos.

El ejercicio de esta facultad por la Administración del Estado no supone, pues, una manifestación de un poder centralista absorbente, sino, como queda dicho, el simple ejercicio de una habilitación de legitimación procesal, que viene a suplir dejaciones de los propios individuos afectados por determinados actos de dichas Entidades locales e inoperancias de la acción popular en las materias en que ésta existe (14).

Por otra parte, ¿por qué esa alarma ante lo que muchos consideran un atentado a la autonomía, sobre todo municipal, sin empezar por inquirir en qué consiste el concepto de autonomía? ¿Es que acaso el uso de esa facultad de impugnar un acto de una Corporación local que se presume ilegal, implica una merma en el potencial autonómico de estas Entidades? ¿Es que estamos tan seguros de los contornos de este tipo de autonomía, como para rechazar esta «intromisión" por parte de la Administración del Estado? ¿No es el concepto de autonomía uno de los más indeterminados de las Ciencias Política y Administrativa?

Efectivamente, el concepto de autonomía abarca desde un extremo, frontero con el de independencia, hasta el opuesto, del Derecho privado, referido a la llamada autonomía de la voluntad de los particulares, base de su capacidad negocial y del principio de respeto a lo pactado ("pacta sunt servanda»), pasando por múltiples formas intermedias, dentro de las Corporaciones de Derecho público, y de sus respectivas esferas de competencias.

Pero es que, sobre todo, si los problemas autonómicos lo que están poniendo en juego son problemas de libertad de actuación, no se debe olvidar que, en último término, el norte que ha de guiar la resolución de los mismos debe fijarse en función de la solución

(14) Util resulta, en este sentido, recordar la cita de José María Boquera Oliver, en el trabajo antes referido - página 127-, de un libro de BANFIELD, comentado por Alonso Olea en la Revista de Estudios Políticos - números 113-114-, sobre los ideales y forma concreta de vida de un pequeño Municipio del sur de Italia, cerca de Potenza. Libro en el que se llega a la conclusión de que la sociedad de aquel Municipio es una sociedad "amoral familiar», en cuanto cada uno de sus componentes cuida y se preocupa única y exclusivamente de sus propios intereses y los de su familia, desentendiéndose por completo de los de la comunidad. 
que salvaguarde mejor la libertad del factor humano, que, como elemento común, sirve de base tanto al Ente fiscalizante (el Estado), como al Ente fiscalizado (la Corporación local de que se trate). En este momento creo que viene muy bien, en refuerzo de mi tesis, esta frase del sociólogo alemán Georg Srmmel (15): «... libertad y sujeción se distribuyen más equitativamente cuando la socialización, en vez de reducir los elementos heterogéneos de la personalidad a un círculo unitario, concede la posibilidad de que lo homogéneo resulte de círculos heterogéneos».

Pensamiento éste con el que pretendo demostrar que el elemento homogéneo e idéntico —el pueblo_, que, siendo uno mismo, sirve, como hemos dicho, de factor componente común del Estado y de sus distintos Entes menores, se podrá sentir más libre si se encuentra con sujeciones de círculos heterogéneos, articulados éstos entre sí por controles y limitaciones, que si su sometimiento es a un solo círculo homogéneo, con poder interno descontrolado.

Mas ahora resulta que con el nuevo Estado de las Autonomías, los controles - con todos los condicionamientos y limitaciones de la institución que nos ocupa- que mediante esta técnica se podían ejercer por parte del Estado sobre los Entes locales, en la práctica van a quedar reducidos casi a cero, puesto que la mayoría de las materias de las que se podrían derivar son aquellas a las que se refiere la Disposición final $5 .^{a}$ de la Ley $40 / 1981$, de 28 de octubre, que en esto reproduce la misma regla de la correlativa disposición del derogado Real Decreto-ley de 16 de enero del mismo año, esto es, materias respecto de las cuales las facultades de impugnación atribuidas por tales normas a la Administración del Estado, corresponderán ahora a las Comunidades Autónomas.

Con este nuevo estado de cosas me temo que Ayuntamientos y Diputaciones van a ver incrementado el número -antes escasode impugnaciones de sus actos supuestamente ilegales, por parte de los órganos de gobierno de sus respectivas Comunidades, mientras que el Estado, ante ellos, va a quedar totalmente inerme. Mi premonición la baso en la hipótesis de que tales órganos van a sentirse más legitimados (legitimados en el sentido schmittiano de la palabra, no en el puramente procesalista) para intervenir mediante la utilización de esta técnica impugnativa, que antes lo estuviera el Estado,

(15) Georg Simmel: Sociología, Bibl. Revista de Occidente, Madrid, 1977, tomo II, página 457. 
al no encarnar aquéllos el espíritu absorbente y centralista que se supone en éste.

Aun a riesgo de ser tachado de extravagante, me atrevo a pensar que el Estado no se ve libre de parecidos complejos a los freudianos, y en estos casos, del complejo de superioridad, que le ha conducido, multitud de veces, a reaccionar en sentido inhibitorio opuesto, como si la intervención mediante el manejo de la técnica que nos ocupa justificara un problema de conciencia, como si la misma implicara por sí un cierto abuso de poder.

De nuevo, volviendo a G. SIM MEL (16), voy a reproducir otra muy aguda frase suya: "Siempre que los intereses de dos elementos se refieren a un mismo objeto, la posibilidad de su coexistencia depende de que haya una línea fronteriza dentro del objeto que separe sus esferas. Esta línea divisoria, si es un límite jurídico, puede significar el fin de la contienda; si es un límite de poder, acaso signifique su comienzo".

El diagnóstico de Sim MEL nos puede servir también, en este punto, para apreciar que la tensión Estado-Municipio puede periclitar entre nosotros, debido a que las líneas divisorias que los separa son puramente jurídicas, y porque el protagonismo que aquél ejercía, frente a éstos, se encuentra en franco declive, dentro del modelo de Estado que hemos adoptado; pero surgiendo en sustitución de esa tensión, otra de muy distinto signo, entre el Estado y las Comunidades Autónomas, al ser tensiones de poder, que son las que, como sostiene este autor, en vez de eliminar la contienda, la provocan.

Ya que nos estamos extendiendo más de la cuenta en la exposición de estas ideas previas, no vamos a incurrir en el exceso de adentrarnos más de lo debido en los problemas surgidos con la creación de estas Comunidades. Nos conformaremos con dejar constancia de que las fisuras que en la estabilidad política de nuestra sociedad han creado, o pueden crear, vienen en gran parte determinadas por factores históricos que han afectado la forma en que se han resuelto, o se han dejado sin resolver, a lo largo del tiempo, los principales temas que han dividido o enfrentado a nuestro pueblo (17).

Pero lo cierto es que, en materia de controles, a estas Comuni-

(16) Georg Simmel: Sociología, tomo II, pág. 653.

(17) Sobre los males sobrevenidos por problemas pendientes, irresueltos o mal enfocados, vid. S. M. LIPSET: "Conflictos sociales, legitimidad y democracia», incluido en un libro titulado El Gobierno: Estudios comparados, de varios autores, Alianza Universidad, Madrid, 1981, pág. 107. 
dades se las sitúa en una posición nada cómoda. Por un lado, vienen a sustituir al Estado, como ya hemos dicho, en la mayoría de las materias en que éste venía ejerciendo el control de legalidad de los actos de Municipios y Diputaciones. Pero, por otro, simultáneamente, quedan en situación de sujetos pasivos, en el control que sobre ellas el Gobierno de la Nación puede ejercer, de acuerdo con las previsiones contenidas en los artículos 153, b), y 155 de la Constitución (18).

Circunstancias éstas que, sin duda, han de provocar situaciones extrañas, sobre todo en estos momentos y en los inmediatos, como consecuencia de la forma en que ha sido resuelto entre nosotros el problema autonómico, a través del Título VIII de la vigente Constitución, el más desafortunado de todos, como es sabido.

El tema autonómico de estas Comunidades se ha convertido en el centro de una vorágine, alrededor del cual giran todas las miradas, moviéndose energías contrapuestas y fuerzas contradictorias. Tema que, con su protagonismo, está dejando tan en la penumbra el de los Municipios, que hasta se corre el peligro, de acentuarse la tendencia, de que lleguemos a olvidarnos de ellos.

Cuando las aguas se serenen y el imprescindible Estado se consolide, superando las tendencias centrífugas, tan a contracorriente de la Historia, será la hora de comprobar que un sistema de libertades, y de gobierno y administración eficaz, no puede basarse en fórmulas extremas, puesto que tan peligroso puede resultar un centralismo absorbente y autoritario, como un cantonalismo disolvente y anárquico. Será la hora de advertir que las Corporaciones locales, con su autogobierno, pueden propiciar el arraigo de la democracia, pero no como lo concibiera tan ilusoriamente J. STUART MILL, ya que, como nos tiene dicho William THORNHILL, no cabe hablar de «democracia local» como concepto independiente y separado de la idea de democracia nacional. Ni, como ha comentado Georges LANGROD, resulta admisible ver en el Régimen local el único marco ideal para la educación política en la democracia, puesto que en ese ámbito, lo más probable es que la política local se limite más bien a reforzar intereses sectoriales con miras más estrechas. Llegando otro autor (Moulin) a sostener que existe el temor de que los intereses creados y la posible corrupción a escala local no resulten con-

(18) Sobre el problema del poder de suspensión del Estado de la ejecución autonómica de sus normas, vid. la obra de E. GARCía DE ENTERRía: La ejecución autonómica de la legislación del Estado, Cuadernos Civitas, Madrid, 1983, págs. 94 y ss. 
ciliables con los altos ideales de la moderna sociedad democrática (19).

\section{ESTUDIO ANALITICO DE LA INSTITUCION}

\section{Naturaleza JURídica}

Vamos a empezar por destacar, al iniciar el estudio de esta segunda parte, que la nota más sobresaliente del cambio legislativo operado por la Ley 40/1981, de 28 de octubre, es la de que, a consecuencia de la misma, y según se recoge en el Real Decreto de 29 de diciembre del mismo año, han quedado derogados, entre otros preceptos, los que en la Ley de Régimen local de 24 de junio de 1955; en el Reglamento de Organización, Funcionamiento y Régimen Jurídico de las Corporaciones locales de 17 de mayo de 1952, y hasta en el Real Decreto-ley 3/1981, de 16 de enero, situaban, en primer término, el acuerdo de suspensión de los actos de las Corporaciones locales, supuestamente ilegales (sin entrar de momento en matizaciones), por parte de los Presidentes de las mismas o de los Gobernadores civiles de las respectivas Provincias, ya que el cambio implica que tal suspensión no se produce por determinación de estas autoridades, sino, ministerio legis, como consecuencia automática de la impugnación de los referidos actos, pero supeditada, en su condición de medida cautelar y provisional, a lo que disponga sobre ello el Tribunal de lo Contencioso competente, quien «deberá ratificarla o levantarla en un plazo no superior a treinta días".

¿A qué obedece este cambio? No creo que la contestación requiera adentrarse en ocultas y recónditas motivaciones, sino en la actitud un tanto vergonzante de reducir en lo posible la actuación de la Administración del Estado, procesalizando y júdicializando al máximo estas operaciones revisoras de la legalidad de ciertos actos -sospechosos- de la Administración local.

Con este recorte en el intervencionismo de la Administración del Estado creo que quedan despejadas todas las dudas tenidas sobre la naturaleza del mismo en esta materia. Ya no se podrá pensar en que se trata de una actuación de tutela, término, por cierto, totalmente inadecuado para expresar la idea que con él se trata de representar, dado el lastre que le proporciona su origen civilístico,

(19) Citas recogidas del libro de Dilys M. Hill: Teoría democrática y Régimen local, I.E.A.L., Madrid, 1980, págs. 24-26. 
a pesar de los esfuerzos realizados por los que, como MASPETIOL y LAROQUE (20), han pretendido darle carta de naturaleza en el Derecho administrativo. Ni será adecuado asociar la institución que nos ocupa con los conceptos a los que se refieren los vocablos «control", «inspección» o «supervisión» (21).

No será adecuado nada de esto porque la Administración del Estado, en este ámbito, ha visto reducida su intervención al modesto papel de parte que impetra la tutela (aquí el término me repugna mucho menos) de un Tribunal de Justicia. El Estado, con toda su "maiestas", baja de su trono y entra por la puerta del público en la sede de uno de sus órganos. El Estado se convierte en simple recurrente, aunque en verdad esto no es rigurosamente exacto del todo, puesto que, como queda dicho, la impugnación del acto recurrido por el Estado de momento se ve sometido a una suspensión, en sus efectos naturales de ejecutoriedad, de forma automática, sin los condicionamientos impuestos en el contencioso ordinario por los artículos 122 y 123 de nuestra Ley Jurisdiccional.

Es en este aspecto en el que se puede basar principalmente la tesis de que el Estado - su Administración-, aun en el papel de recurrente, dispone de una prerrogativa que, con la Ley 40/1981, se ha procurado difuminar, haciendo aparecer la suspensión del acto no como una determinación de su Administración, sino como un efecto del proceso por la misma revocado. Una prerrogativa instrumentalizada procesalmente, y que por eso mismo se diluye y desvanece, porque la misma no viene a otorgar otra cosa que una legitimación para residenciar ante nuestra jurisdicción a ciertos actos de las Entidades locales sospechosos de ilegalidad. Legitimación que fue calificada por BOQUERA OLIVER de "extraordinaria» (21 bis), aunque yo dudo que lo sea, ya que ningún órgano de la Administración del Estado puede ser considerado órgano de la Administración local, sino de la central o periférica de aquélla, y, por tanto, no puede verse comprendido en el supuesto previsto en el artículo 28, número 4, apartado a), de la Ley de 27 de diciembre de 1956, pues por lo mismo que, como proclamó la sentencia de 4 de junio de 1963, no puede estimarse falto de legitimación a un Ayuntamiento para impugnar un acto del Estado con arreglo al citado número 4 del artículo 28 de la Ley Jurisdiccional, por no poder considerarse que una Dipu-

(20) Maspetiol y LAROQUE: La tutele administrative, París, 1930.

(21) E. GARcía DE ENTERRfA: La ejecución autonómica de la legislación del Estado, pág. 135.

(21 bis) José María Boquera Oliver, trabajo antes citado, pág. 126. 
tación o un Ayuntamiento -cualquiera de sus órganos- pueden ser estimados órganos de la Administración del Estado; tampoco los órganos de ésta, como queda dicho, pueden ser calificados de órganos de esas Corporaciones locales.

En lo único en que se puede considerar a esta legitimación como extraordinaria es en el hecho de que la misma se basa, más que en el interés directo exigido en el apartado a) del número 1 del repetido artículo 28 de la Ley Jurisdiccional, en un interés por la ley, que viene a representar un interés colectivo, objetivado.

Se trata de una legitimación que viene a ser extendida verticalmente, en relación con la extensión horizontal que la misma sufre a través de la acción popular. En ambos casos, la existencia de un interés general viene a sustituir (sustitución procesal) al interés específico, concreto y directo de las personas posiblemente afectadas. No en vano, en un libro que tengo dedicado por el que fuera Oficial Mayor del Ayuntamiento de Sevilla, Antonio de la ORDEN DoMínGUEZ (22), los acuerdos de suspensión de actos de las Corporaciones locales, y los recursos promovidos o impulsados por una acción popular, son tratados en sendos capítulos del mismo, homogeneizando, en una visión intuitiva, instituciones que, en apariencia, nada tienen de común.

Empero, lo importante es anotar que frente a actos supuestamente ilegales de las Corporaciones locales, la Administración del Estado, pese a que la autonomía de aquéllas jamás podrá equivaler a soberanía, siendo por ello compatible con la existencia de controles de legalidad sobre el ejercicio de sus competencias, como tiene proclamado el Tribunal Constitucional en su sentencia de 2 de febrero de 1981, a pesar de todo, el Estado se ha autolimitado al máximo, consintiendo, como repetidamente hemos dicho, que su papel en este campo quede reducido al modesto de simple recurrente.

Por esto, las calificaciones de Jesús Leguina Villa (23), formuladas a principios de 1977, al referirse a la «tutela del Estado sobre Ayuntamientos y Diputaciones", a un "poder excepcional de control», a «facultades de control suspensivo de las autoridades estatales». y otras frases semejantes, han quedado en la actualidad desprovistas de sentido, ya que el Ejecutivo sólo puede ahora trasladar el acto

(22) Antonio DE LA ORDEN Domf́nguez: Algunos problemas de régimen juridico local en torno a la acción popular, Sevilla, 1958.

(23) Jesús Leguina Villa: "La potestad gubernativa de suspensión de acuerdos. locales que infrinjan manifiestamente las leyes: alcance y límites», en Rev. Adm. Pública, núm. 82, enero-abril 1977, págs. 9 y ss. 
sospechoso de una Corporación local al Tribunal competente, siendo éste el único que ejercitará el control.

Creo que sería muy conveniente que los juristas adquiriéramos conciencia de este estado de cosas, y que ya que el Estado está renunciando a tanto, hasta el punto de que la llamada "razón de Estado" nadie se atreve a invocarla, por lo menos, que los Tribunales no nos carguemos lo poco que el Estado se ha reservado, con interpretaciones restrictivas, so pretexto de la supuesta excepcionalidad de este imaginario poder de control que se atribuye a la Administración estatal.

\section{ENTES Y ÓRGANOS A LOS QUE SE ATRIBUYE ESTA LEGITIMACIÓN}

Hasta aquí, en aras de la simplificación, a la vez que con el propósito de destacar las relaciones Estado/Corporaciones locales, he centrado la atención en el papel del primero, como titular de la prerrogativa a que me vengo refiriendo. Mas al descender al estudio analítico de la institución, resulta forzoso concretar en quiénes, en concreto, queda localizado el ejercicio de la legitimación activa de que se trata.

En el anterior ordenamiento (Ley de Régimen local, arts. 362 y 365; Ley de la Jurisdicción, art. 118) esta localización no podía ser más precisa y acorde con la elementalidad del sistema: estaba fijada en los Presidentes de las Corporaciones locales y en los Gobernadores civiles (facultad que figuraba también, respecto a éstos, en el artículo 13, núm. $3 .^{\circ}$, párrafo último, de su Estatuto, aprobado por Decreto de 10 de octubre de 1958).

En el ordenamiento actual, constituido principalmente por la Ley $40 / 1981$, de 28 de octubre, el problema se ha visto complicado en gran medida, sobre todo como consecuencia de la estructuración del nuevo Estado de las Autonomías. Así, la impugnación de actos supuestamente ilegales de las Corporaciones locales puede proceder: a) del Estado; b) de las Comunidades Autónomas; c) de miembros de las propias Corporaciones.

\section{a) Del Estado}

A diferencia de la normativa anterior, la vigente, constituida, como queda dicho, por la Ley 40/1981, de 28 de octubre, antecedida por el Real Decreto-ley 3/1981, de 16 de enero, en vez de referirse 
a los Gobernadores civiles, sólo habla de la Administración del Estado, lo que revela el propósito de no mantener la exclusiva, en este tipo de función, de tales autoridades provinciales, aunque tampoco su exclusión, puesto que, en su condición de órganos periféricos, y pese a que son más gubernativos que administrativos, no dejan de pertenecer al engranaje de la Administración del Estado. Sin que a esta interpretación se oponga la inexistencia en su nuevo Estatuto, aprobado por Real Decreto de 22 de diciembre de 1980, de un precepto análogo al antes referido, del anterior, de 10 de octubre de 1958, ya que tal vacío no debe interpretarse como una voluntad de eliminar a los Gobernadores civiles de estos cometidos, por ser consecuencia de la forma en que se ha acometido la redacción de dicho Real Decreto de 22 de diciembre de 1980, sustituyendo el casuismo del Estatuto antiguo por la síntesis del nuevo texto reglamentario.

Los Gobernadores civiles incluso no sólo pueden verse legitimados para ejercitar este tipo de impugnaciones por una legitimación directa, como órganos estatales, sino también por una legitimación por subrogación, en lugar de las Comunidades Autónomas, dentro de sus respectivas Provincias, por inactividad de las mismas, esto es, cuando pudiendo haber impugnado un acto de uno de sus Municipios, no lo hubieran hecho, tal y comó se prevé en el artículo 1, 4, 1. , del Real Decreto 2115/1978, de 26 de julio —respecto a Cataluña-, y en el correlativo del Real Decreto 2488/1978, de 25 de agosto -respecto al País Vasco-, y como viene siendo corroborado por la jurisprudencia (sentencias del Tribunal Supremo de 16 de julio de 1982 y 20 de abril de 1983, entre otras).

Jurisprudencia que lo que ha hecho es matizar y limitar el ámbito de actuación de los Gobernadores en esta materia, habilitándolos para sólo los supuestos en que las Corporaciones locales invaden competencias del Estado o simplemente se inmiscuyen en asuntos que no son propios de ellas. Pudiéndose traer a colación, a este respecto, la doctrina sentada por el Tribunal Constitucional en sus sentencias de 2 de febrero y 29 de abril de 1981 y 27 de julio de 1982.

\section{b) De las Comunidades Autónomas}

La repetida Ley 40/1981, de 28 de octubre, en su Disposición final $5 .^{a}$, reproduce un precepto ya contenido en la correlativa del Real Decreto-ley de 16 de enero del mismo año, y que literalmente dice así: «Las facultades de impugnación atribuidas por la presente 
Ley a la Administración del Estado corresponderán a las Comunidades Autónomas, en relación con las competencias que hayan asumido y de acuerdo con lo establecido en sus respectivos Estatutos de Autonomía».

Así, pues, serán las respectivas competencias las que delimitarán los campos de intervención del Estado y de las Comunidades Autónomas respecto de la institución que nos ocupa, debiendo entenderse derogados los preceptos que, como los contenidos en el artículo. $1,4,1^{\circ}$, de los Decretos de transferencia de competencias a la Generalidad de Cataluña y al Consejo General del País Vasco de 26 de julio y de 25 de agosto de 1978, respectivamente, atribuían a los. Gobernadores civiles atribuciones para suspender e impugnar acuerdos supuestamente ilegales de las Corporaciones locales, de sus Provincias, de no haberlo hecho los órganos de gobierno de esas Comunidades.

\section{c) De las Corporaciones locales}

La posibilidad de que un órgano de estas Corporaciones pudiera impugnar actos de las mismas, empezando por la suspensión de su ejecución, estaba consagrada, como es sabido, en el anterior ordenamiento, y prevista como excepción a la prohibición general del número 4 del artículo 28 de nuestra Ley Jurisdiccional, en el apartado a) del mismo número y artículo de la Ley. Posibilidad que en el nuevo régimen se mantiene, pero no monopolizada por sus Presidentes, ya que ha sido extendida a cualquiera de sus miembros, siempre que en la sesión donde el acuerdo hubiera sido adoptado, no lo hubieran votado favorablemente, como exige el artículo 9 de la repetida Ley 40/1981, de 28 de octubre. Creyendo innecesario repetir que, en estos casos, como en los demás, la suspensión de los efectos ejecutivos del acto se produce no por acuerdo del impugnante o impugnantes, sino por ministerio de la ley, como consecuencia de su residenciamiento jurisdiccional. Cambio de criterio que obedece a un designio democrático de igualación de papeles entre los componentes de una misma Corporación local.

\section{EL PROCESO PROMOVIDO POR ESTE TIPO DE IMPUGNACIONES}

La rúbrica de este apartado ya anticipa algo de lo que es obvio hoy día. Ya nadie discute que la impugnación de actos de las Corporaciones locales, a que nos venimos refiriendo, ante los Tribuna- 
les de lo Contencioso, provoca la iniciación por los mismos de un auténtico proceso. La doctrina no pone esto en cuestión y la Ley de la Jurisdicción lo da por supuesto, partiendo de la idea básica de que toda su regulación es procesal, sin distinciones, como la establecida en la Ley de Enjuiciamiento Civil, entre jurisdicción contenciosa y voluntaria, sino simplemente concediendo a este proceso la consideración de especial, incluyéndole por ello dentro del Capítulo IV del Título IV de la Ley (Sección 2. ${ }^{a}$ ), junto con los otros dos calificados de igual forma (los de las Secciones $1 .^{a}$ y $3 .^{a}$ ), en contraste con el proceso ordinario del Capítulo I del mismo Título.

La especialidad viene determinada por razones de fondo, por el conjunto de las circunstancias subjetivas y objetivas que configuran la pretensión deducida en este tipo de proceso, que son las que han aconsejado sacarlo de la tramitación del proceso ordinario, creando para el mismo una regulación ad hoc, lo que constituye una demostración de que el fondo y la forma no operan como elementos separados, puesto que siempre existe entre ellos una íntima interconexión, influyendo el uno sobre el otro. No obstante, como hemos dicho, la especialidad de este proceso no le hace perder su sustancia procesal, puesto que la misma sólo tiene una traducción a nivel de procedimiento, siendo éste el que le hace aparecer como proceso distinto al ordinario, caracterizado principalmente por su sumariedad.

En cuanto a las razones de fondo, acabadas de aludir, vienen singularizadas por los motivos tasados en que la pretensión puede fundarse, y por los pronunciamientos, también tasados, que los Tribunales pueden dar como respuesta a los mismos.

Si no fuera porque los autores de nuestra Ley Jurisdiccional de .27 de diciembre de 1956 tanto se esforzaron por liberarse del vasaIlaje existente entre nosotros, respecto del contencioso francés, como lo evidencian las palabras de su Exposición de Motivos, y el énfasis que ponen en la tarea de superación de la dicotomía procesal de anulación/plena jurisdicción. Si no fuera por eso, repetimos, sumaríamos a lo dicho en este apartado, sobre la naturaleza del proceso en estudio, el dato del carácter de éste, como proceso objetivo de anulación (24), en el que las partes no se mueven alrededor de un concreto derecho subjetivo, ni siquiera en beneficio de un interés directo, sino de un interés genérico por el imperio de la legalidad, aunque esta legalidad, como después veremos, haya sido tomada,

(24) Fernando Garrido Falla: «El recurso subjetivo de anulación», en Rev. Administración Pública, núm. 8, mayo-agosto 1952, págs. 177-189. 
como causa habilitante del proceso, en una de sus manifestaciones específicas: la de la competencia del órgano autor del acto de que se trate. Es por esto, de todas formas, por lo que aquí tiene cabida la conocida frase de M. Hauriou de ser "un proceso al acto». Un proceso que de prosperar la pretensión en él deducida, sólo puede terminar con el restablecimiento del imperio de la ley, sin otras repercusiones inmediatas materiales.

\section{ACtOS IMPUGNABLES}

\section{a) Que se trate de actos o acuerdos}

Jesús González Pérez (25), en contra de la opinión de otros autores (Alvarez Gendin, Trujillo, Quintana y Bolea y Pera VerdaGUER), ha sostenido, a nuestro juicio con razón, que lo impugnable en estos casos son actos o acuerdos, y no disposiciones de carácter general. Opinión que ha venido a confirmar la nueva normativa, con su expresión, rotundamente manifestada, de que la impugnación tiene que referirse a «actos o acuerdos». Términos tan claros que forzosamente ponen en juego el apotegma inclusio unius, exclusio alterius.

\section{b) Que se trate de auténticos actos administrativos}

En sentencia de la Sala $4 .^{\mathrm{a}}$ del Tribunal Supremo - ponencia nuestra- de 8 de junio de 1983, ha quedado expuesta la siguiente doctrina:

"CONSIDERANDO: Que aunque doctrinalmente no se ha llegado a un acuerdo en la delimitación del concepto del acto administrativo, sin embargo, sí que existe en lo que se refiere al concepto restringido del mismo, que es el que se ha de tener en cuenta en supuestos como el que nos ocupa, referido a la suspensión, por el Gobernador civil de Cuenca, del acuerdo de..., del Ayuntamiento de...».

"ConsIDERANDo: Que el tipo de acto administrativo que ha de servir de presupuesto para la habilitación de acuerdos de suspensión como el adoptado en este caso por el Gobernador civil, es el definidor de derechos y obligaciones, el que actualiza la voluntad

(25) Jesús González Pérez: Comentarios a la Ley de la Jurisdicción Contenciosa Administrativa, Ed. Civitas, Madrid, 1978, pág. 1290. 
de la ley y la aplica en el caso concreto, incidiendo en la realidad jurídica, creando, modificando o extinguiendo una determinada relación jurídico-administrativa...».

Doctrina que sirvió, en el supuesto enjuiciado por esta sentencia, para anular el acuerdo de suspensión del referido Gobernador civil, por el solo motivo de que el acuerdo del Ayuntamiento por él suspendido e impugnado no reunía las condiciones exigidas para ser considerado como auténtico acto administrativo, pese a la laxitud con que ciertos autores configuran el mismo (26).

Doctrina en la que ya se había basado la Sala de lo Contencioso de la Audiencia Territorial de Pamplona en varias sentencias dictadas durante el mes de noviembre de 1976, todas ellas idénticas en su motivación y fallo, ampliamente comentadas por J. LEGUINA Villa en el trabajo anteriormente citado.

\section{c) Que emanen de una Corporación local}

Tanto en el anterior ordenamiento como en el vigente, el campo en el que se podía producir este tipo de impugnaciones no podía estar más delimitado. Sólo podía tratarse de actos emitidos por las Corporaciones locales. Esto es, por Juntas Vecinales de Entidades Locales Menores, Ayuntamientos y Diputaciones Provinciales.

\section{FUNDAMENTO DEL ACUERDO IMPUGNATORIO}

Como ya hemos dicho, una de las singularidades de este proceso obedece al hecho de que el mismo se ha de iniciar en virtud de una pretensión que, como ha puesto de relieve J. GonzÁlez Pérez (27), no podrá fundarse en cualquier clase de infracción del ordenamiento jurídico, según se prevé con carácter general en el artículo 83 de la Ley Jurisdiccional, sino en la que constituye el objeto específico del mismo, esto es, en la causa tipificada por el legislador, que es la habilitante del contencioso, conforme viene reconociendo la jurisprudencia (por todas, sentencia de 9 de abril de 1968).

Esta causa, considerada fundamentalmente como motivo de suspensión de acuerdos de las Corporaciones locales, diversificada en

(26) Un ejemplo, entre estos últimos, es el que nos viene dado por Guido ZaNoBINI, en su Curso de Derecho administrativo, Ed. Arayú, Buenos Aires, 1954, pág. 311, para quien acto administrativo sería «una declaración concreta de voluntad, de opinión, ¿de juicio, de ciencia, del Estado o de otro sujeto del derecho público administrativo».

(27) Jesús González Pérez, ob. cit., pág. 1290. 
diversos supuestos en el Estatuto municipal de 8 de marzo de 1924, y más tarde en la Ley de Bases de Régimen local de 17 de julio. de 1945, no seguida fielmente en todos sus detalles por la Ley articulada de 16 de diciembre de 1950, ni por el Texto Refundido de 24 de junio de 1955, quedó reducida en el artículo 118 de nuestra Ley Jurisdiccional, tras del distinto tratamiento dado a los cuatro motivos que podían fundarla (distinción entre los tres primeros y el último), al recogido en éste: que el acuerdo incurra en infracción manifiesta de las leyes. Motivo que ha sido cambiado en la Ley vigente, tantas veces citada, de 28 de octubre de 1981, a pesar de que en su artículo $8,1 .^{\circ}$, se formula una remisión a dicho artículo 118 , ya que se trata de una remisión a los solos efectos procedimentales, pero no de fondo, al que pertenece la causa en cuestión.

De acuerdo con lo establecido en ese número 1 del artículo 8 de la Ley $40 / 1981$, de 28 de octubre, la posibilidad de impugnar actos. de las Corporaciones locales por la Administración del Estado está supeditada a que éstos "constituyan infracción de las leyes» y "afecten directamente a materias de la competencia del Estado".

$\mathrm{Ha}$ desaparecido en este nuevo texto legal el requisito de que la infracción de las leyes sea manifiesto (en buena hora), pero, en contrapartida, se exige que los actos «afecten directamente a materias de la competencia del Estado". Los dos requisitos vienen formulados no alternativamente, sino conjuntamente, no sólo por venir unidos por la conjunción copulativa "y», sino porque sí vino a interpretarlo el artículo 5 del Real Decreto 1262/1981, de 5 de junio; disposición que, aunque referida al Real Decreto-ley 3/1981, de 16 de enero, mantiene su vigencia en todo lo que, como en este extremo, no se oponga a la Ley 40/1981, según se establece en el artículo 2 del Real Decreto 3183/1981, de 29 de diciembre.

Que hayan eliminado el requisito de que la infracción tenga que ser manifiesta para poder ser causa de la impugnación del acto merece, a mi juicio, toda clase de plácemes. Y ello por dos razones: $1 .^{a}$, porque ese requisito no venía a cumplir otro cometido que el de cercenar el número de casos en que este tipo de pretensiones, ejercitadas por agentes del Estado o de las propias Corporaciones, podían deducirse, lo cual se ha conseguido por otra vía, por la de la: incompetencia; $2{ }^{2}$, porque con ello se evitan los juegos de pirotecnia verbal de los Tribunales, encaminados, en una rebusca de sinónimos, a explicar el concepto de "manifiesta», el cual depende, en buena parte, y eso es lo malo, más que de la objetividad del fenómeno, de. 
las capacidades gnoseológicas de los intérpretes. Circunstancia que deja la solución del problema, en múltiples casos, a merced de la visión subjetiva de los juzgadores y de sus criterios personales.

La fórmula de división de las infracciones en "manifiestas» y "no manifiestas" es arbitraria y utópica. Es además incompatible con la condición del Derecho, insusceptible por naturaleza de ser parcelado entre lo aporético y lo axiomático. En Derecho hay que renunciar de antemano a la idea de lo absoluto, de lo evidente y de lo no evidente. El Derecho es esencialmente y todo él problemático. ¿Cómo no va a serlo si el mismo Derecho natural no es un sistema dado de una vez por todas, sino que ha de ser "buscado", "descubierto"? (28). ¿Cómo no si hasta los mismos matemáticos han renunciado a la consideración de su ciencia como bastión de infalibilidad y de certeza irrefutable? ( 28 bis).

Incluso los lógicos, en su esfuerzo por acotar conceptos y valores, van superando sus antiguas dicotomías, mostrándose más sutiles, con clasificaciones trivalentes, como la recogida por Ulrich KLUG (28 ter): a) imposiblemente verdadero; b) posiblemente verdadero; c) necesariamente verdadero. 0 llegando a una lógica plurivalente, con una escala continua, no discreta, de valores lógicos, como es el caso del filósofo científico Hans REICHENBACH. Lógica que termina por subsumir el concepto de Verdad en el de Probabilidad.

Si la Verdad deviene discutible y movediza, qué no ocurrirá con la Certeza y con la Evidencia, conceptos sólo aproximativos de aquélla. Y no digamos nada de la Claridad, cuya base, en la construcción del apotegma jurídico "in claris non fit interpretatio", es uno de tantos mitos en circulación en el Mundo del Derecho.

Mito ingenuamente sostenido en tantas resoluciones judiciales hasta elevarlo a la categoría de principio general hermenéutico, aunque puesto en cuarentena en alguna que otra sentencia, como sucede con la de la Sala 4. ${ }^{\text {a }}$ del Tribunal Supremo de 12 de junio de 1972 (Aranzadi 3.170), recogida en el libro de J. L. Villar Palasí La Interpretación y los Apotegmas Jurídico-Lógicos (pág. 113); sentencia de la que fui ponente en mi primera etapa como eventual en dicha Sala, y en la que recogí una idea de Joaquín DuALDE, vertida en su

(28) Eduardo García de EnTERrfa, en su prólogo al libro de Theodor Viehweg: Tópica y jurisprudencia, Ed. Taurus, Madrid, 1964, pág. 15, recoge en este sentido el pensamiento de ARANGUREN.

(28 bis) Miguel DE GUZMÁN OzÁMIz: "Sobre la educación matemática», trabajo inserto en el número 26 de la Revista de Occidente, junio-julio 1983, pág. 41.

(28 ter) Ulrich Klug: Logica jurídica, Publicaciones de la Facultad de Derecho, 'Caracas (Venezuela), 1961, pág. 43. 
libro Una revolución en la lógica del Derecho (Ed. Bosch, Barcelona, 1933).

En definitiva, el que una infracción del ordenamiento administrativo deba ser tomada en consideración tendrá que depender de que la misma exista o no exista y no de su mayor o menor grado de. ostensibilidad. Otra cosa distinta es que sea tan minúscula, tan irrelevante, que por pura economía no merezca la pena tomarla en cuenta. Ni en el proceso especial que nos ocupa ni en el ordinario.

Ahora bien, si el proceso especial se abre, ¿por qué consumirlo. para llegar a la conclusión final inútil de no anulación del acto, en base a que la supuesta infracción no es manifiesta, si en realidad, aunque esto sea cierto (con las reservas antedichas), la infracción existe? ¿Por qué malgastar todo un proceso por no darse un dato fundamentalmente basado en elementos de certidumbre y de evidencia, precisamente en un proceso en que la certidumbre no se intenta buscar al no estar prevista en el mismo la fase probatoria? ¿Qué es más importante: que la infracción exista o no exista, o que sea manifiesta o no manifiesta?

Si me he detenido más de la cuenta en combatir el concepto de "infracción manifiesta», a pesar de que el cambio legislativo producido con la promulgación de la Ley 40/1981 lo elimina, es sólo para ofrecer puntos de reeflxión sobre el mismo y para contribuir en lo posible a su no resurrección, ya que conatos no faltan, como ocurre con el «Anteproyecto de Ley de Revisión de la Ley de la Jurisdicción Contencioso-administrativa", al parecer terminado a mediados de 1980 y en la actualidad en dique seco, ignorando en este momento su destino y si se trabaja o no ahora en otro distinto.

Quiero anotar también desde otro ángulo que este cambio legislativo representa en el proceso especial de que se trata el sentido inverso seguido en las causas que lo motivan respecto del recorrido en la historia del contencioso ordinario del Derecho francés, en el que, como es sabido, el recurso por exceso de poder se inició por el vicio de incompetencia, terminando la lista con el de violación de la ley, que vino a rematar el repertorio de motivos habilitantes de su apertura, aunque sin sustituir el uno por el otro, sino de forma. acumulativa.

El proceso especial del artículo 118 de la Ley Jurisdiccional, por el contrario, montado sobre la causa ya dicha de la infracción de la ley con el condicionamiento de que sea manifiesta, ha visto trastocada la misma por la incidencia que en este artículo necesariamente: 
ha producido la tan repetida Ley 40/1981, al basar la infracción de ley en motivos de incompetencia en el actuar de las Corporaciones locales.

Sin duda que en este cambio legislativo mucho ha tenido que ver la jurisprudencia del Tribunal Constitucional sobre autonomía de estas Corporaciones al efectuar su labor revisora sobre la base de la distinción entre competencias propias y competencias delegadas.

En realidad, con esta yuxtaposición de infracción de ley e incompetencia no se violentan sus respectivos conceptos, porque, en último término, la incompetencia, el vicio de forma, el delito o el acto contrario al orden público son todos ellos actos que violan la ley de una $\mathrm{u}$ otra forma.

Sin embargo, el legislador, al destacar uno de estos vicios -el de incompetencia-, erigiéndolo en causa única de la suspensión e impugnación del acto, no ha obrado arbitrariamente, pues ha obedecido a un criterio sólido, con respaldo en los antecedentes históricos de la institución y en el Derecho comparado. En efecto, al defender MAURA su segundo proyecto de Ley de Régimen local de 1907 declaraba: «El Gobernador, en esta Ley y en todas las leyes que se puedan imaginar, es el guardián del límite exterior del perímetro de la competencia municipal; ¡no faltaría más!, como que es el representante del Gobierno" (29). Idea que se recoge en el segundo párrafo del artículo 245 de dicho proyecto, al declararse que «serán reputados y declarados nulos cualesquiera acuerdos de Corporaciones o autoridades locales que hayan excedido el límite de la competencia municipal definida por esta Ley». El Estatuto municipal de 1924, por su parte, aunque no como motivo exclusivo, señala en su artículo 193, 3. , entre las atribuciones del Alcalde, como Jefe de la Administración municipal y Presidente del Ayuntamiento, la de «suspender los acuerdos municipales... cuando recaigan en asuntos extraños a la competencia municipal». Incluso en su artículo 260 se concede al Gobierno, aun en contra de la resolución de los Tribunales, la facultad de acordar con carácter extraordinario la suspensión del acuerdo que los Ayuntamientos hayan adoptado, extralimitándose de la competencia municipal, cuando exista alguna de las causas que enumera el artículo 84 de la Ley de 22 de junio de 1894. Igualmente, la Ley municipal de 1935 obliga a los Alcaldes y faculta a los Gobernadores para suspender los acuerdos municipales en materia extraña a su competencia. Lo cual se recoge en el número 1 del párrafo $2 .^{\circ}$ de la

(29) José María Boquera Oliver, trabajo antes citado, pág. 110. 
Base LVI de la Ley de 17 de julio de 1945, así como en el apartado $1 .{ }^{\circ}$ del número 1 del artículo 362 del Texto Refundido de 24 de junio de 1955, aunque tampoco como causa exclusiva.

Dentro del Derecho comparado se puede traer a colación desde la sentencia de 21 de septiembre de 1886 del Tribunal Supremo Administrativo de Prusia (30), en la que después de sentar unos principios generales sobre la amplia gama de funciones que pueden acometer los Municipios formula la reserva de que éstos siempre estarán sujetos a la restricción de no poder dedicarse más que a la administración de los intereses locales, "porque de otro modo se convertirían sus actos normales en verdaderas extralimitaciones", hasta la citada por Luciano PAREJo Alfonso (31) del Tribunal Constitucional Federal alemán, relativa a los acuerdos de los Municipios del Land Hessen sobre celebración de referéndum sobre armas atómicas, en la que se declara que por "asuntos de la comunidad local» habrán de entenderse aquellos «que están enraizados en la comunidad local o que tienen una específica relación con ésta y pueden ser resueltos por la misma de forma independiente y bajo la propia responsabilidad». Citando Parejo la opinión de E. Forst hoff sobre el tema, al decir que «con la limitación a los asuntos de la comunidad local se prohíbe a los Municipios hacer objeto de su actuación los asuntos de la gran política».

El ser o no ser competente es, pues, el factor determinante para que el Estado tenga o no tenga que respetar la actuación de los Entes locales. Ahora bien, que nadie piense que con ello se ha dado con la fórmula mágica que deja resuelto de antemano toda clase de problemas. Ninguno de éstos es tan difícil, como atinadamente ha expuesto Harold J. LASKI (32), en la Administración local como el de fijar la competencia de sus Entidades. Porque el concepto de competencia, decimos por nuestra parte (perdón, el que dice nosotros - ha dicho Croran- miente), y eso es lo malo, no es un concepto cerrado, lo contrario de lo que muchos han pensado de él, y por lo que les ha llevado a emplear términos que en su semántica traducían la idea de las áreas competenciales como sinónimas de áreas geométricas, con perímetros, diríamos, físicamente perceptibles. Porque cada vez es mayor el número de competencias concurrentes

(30) Sentencia citada por Harold J. LASKI: El Estado moderno, Librería Bosch, Barcelona, 1932, tomo II, pág. 162.

(31) Sentencia citada por Luciano Parejo Alfonso: Garantía institucional y autonomías locales, Instituto de Estudios de Administración Local, Madrid, 1981, pág. 66.

(32) Harold J. LASKI, ob. cit., tomo II, pág. 153. 
o compartidas y porque no siempre es fácil de establecer la separación entre competencias propias y competencias delegadas.

La competencia, tengo dicho en un libro que voy a morir sin verlo terminado ( $¡$ Dios no lo quiera!), es el cupo de poder de que dispone cada órgano de la Administración para poder actuar con validez dentro del campo que se le tenga asignado (jerárquico, territorial y material). Concepto reconocido explícitamente, o implícito, que es el que ha motivado el que se pudiera airear la idea triunfalista del "pouvoir municipal», construida, como se sabe, por TURGOT (33) con nobles fines (con la de sustituir el principio de orden estamental, de personalidad de los derechos y de verticalidad de los estamentos, por un orden social nuevo, de territorialidad de los derechos. sociales y de horizontalidad uniforme en su distribución). TURGoT insiste mucho en que este poder ha de abarcar únicamente asuntos. a la medida de las personas miembros de estas comunidades; asuntos casi de la misma naturaleza de aquellos que cada uno toma voluntariamente para gobernar sus propios bienes; funciones simples que no estarán por encima de la capacidad de nadie en el lugar que habita. Subrayando que no se trata de cuestiones políticas, de una sustracción de auténticas competencias del Estado. No se trata, insiste, de quitar al Estado algo propio, sino más bien de una auténtica devolución por el Estado de funciones que no están en su ámbito. peculiar.

Pero, ¿de qué valen las explicaciones que puedan darnos los tratadistas, por sabios y famosos que sean, sobre el concepto de competencia y sobre los contenidos concretos que a ésta deba corresponder según la Administración pública de que se trate y el órgano a. que se haga referencia? Estas opiniones, como fuentes indirectas del Derecho, podrán influir en el legislador; mas cuando éste ha tomado. partido por una u otra solución, y cuando ésta no vulnera el orden constitucional, será su obra - la ley - la única que con su suprema-. cía (la expresión es de Otto MAYER) habrá de tenerse en cuenta, con los desarrollos reglamentarios que puedan dictarse en lo secundario. y sin infringir la misma.

De esto se deduce que la organización competencial de un Estado - de él mismo y de sus Entes menores- constituye materia sometida a la reserva de ley (expresión igualmente acuñada por 0 . MA-

(33) Como comprenderéis, estas ideas están recogidas del trabajo de Eduardo. GARCÍA DE ENTERRfa sobre «Turgot y los orígenes del municipalismo moderno», publicado en la Rev. Adm. Pública, núm. 33. 
YER) (34). Ley estatal, porque si, como dijo G. JELLINEK (35), la primera condición que ha de reunir un poder de dominación independiente es que su organización descanse sobre leyes propias, es obvio que como las Corporaciones locales carecen de soberanía e independencia, su organización no puede depender de la voluntad de las mismas, ya que ni siquiera las Comunidades Autónomas ostentan poder para sentar las bases de su régimen jurídico ni de las Corporaciones de su territorio, conforme a lo estatuido en el número 18 del artículo 149 de nuestra Constitución.

Ahora bien, las reservas de ley sólo pueden garantizar la sustracción de sus respectivas materias del ámbito del Poder ejecutivo e incluso ni siquiera esto, puesto que cabe su incumplimiento en la realidad, aunque frente a estas eventualidades siempre se cuenta con los dispositivos reparadores de la intervención de los Tribunales de Justicia. Como cabe también que contando con una perfecta organización competencial, luego, en la práctica, los actos particulares incurran en vicios, basados precisamente en la competencia. Vicios que no suelen aparecer en función de su consideración de principio general y abstracto, sino referido a sus plasmaciones concretas, en las que cuenta mucho la división en distintas clases de aquel principio, que es lo que principalmente motiva el que se produzca el planteamiento de una gradación, dentro de los vicios de incompetencia, calificándolos de graves o menos graves, de insubsanables o subsanables, hasta toparnos de nuevo en este camino con el concepto por el que tanta aversión sentimos: con el de incompetencia manifiesta, tomado por la Ley de Procedimiento Administrativo (art. 47, 1, a) como requisito para que el vicio produzca la nulidad radical o absoluta del acto.

Aunque sería impertinente que nuestra crítica la extendiéramos a este precepto legal, ajeno por completo al tema que nos ocupa, lo que en este momento interesa puntualizar es que la existencia y vigencia de la norma contenida en el citado artículo 47, 1, a), de la Ley de Procedimiento Administrativo, y con ella la del concepto de «incompetencia manifiesta", a los efectos prevenidos en la misma, no constituye el menor obstáculo para que el repetido concepto no juegue el más mínimo papel en el campo reservado a la institución en estudio, pues ni existen razones para considerarse obligados a apli-

(34) Dietrich Jesch: Ley y Administración, Instituto de Estudios Administrativos, Madrid, 1978, pág. 38.

(35) Georg Jellinek: Teoría general del Estado, Ed. Albatros, Buenos Aires, 1978, pág. 369. 
car aquí la analogía, ni ésta puede sobreponerse a un precepto del mismo rango, como es el del artículo $8 .^{\circ}, 1$, de la Ley $40 / 1981$, de 28 de octubre, posterior en el tiempo a aquel otro y de contenido específico.

El que la competencia o incompetencia sea o no manifiesta no debe convertirse en un prius que sirva para desviar la solución que corresponda, de acuerdo con la objetividad del problema, por encima del esfuerzo gnoseológico que haya que efectuar hasta captar su plena realidad. Así pues, la Administración del Estado estará perfectamente legitimada para pretender la anulación de un acuerdo de una Corporación local si entiende invade la zona de sus atribuciones y los Tribunales deberán entrar en el enjuiciamiento del fondo del asunto, sin detenerse en estadios intermedios, hasta agotar el tema.

Si la competencia es irrenunciable (art. $4 .^{\circ}$ de la Ley de Procedimiento Administrativo) y puede declararse de oficio (art. $80^{\circ}$ de la Ley de Procedimiento Administrativo). Si el Derecho estatal goza de prevalencia sobre el regional y local (36), entonces, ¿qué es lo que puede justificar el que se establezcan cercenamientos en la labor enjuiciadora de un conflicto competencial de este tipo? La contestación me parece obvia: nada puede justificar el establecimiento de requisitos entorpecedores en esta mision.

Poner trabas a que la Administración del Estado recupere competencias propias me parece algo que no tiene sentido. Es llegar al punto extremo, opuesto a aquel otro, inicial, del Estado absoluto, en el que el Estado lo era todo. Y desde cuya perspectiva, como agudamente ha apuntado Prosper WeIl (37), la existencia misma del Derecho administrativo resulta en cierto modo milagrosa. Puesto que resulta extraño, como señala este autor, que el Estado haya llegado a considerarse obligado por la ley que él mismo ha dictado. Ya que está en la naturaleza de las cosas - dice- el que un Estado crea de buena fe estar investido de poder para decidir discrecionalmente sobre el contenido y las exigencias del interés general. $\mathrm{Y}$ que conste que WEIL, por su modernidad, no está inscrito en la lista de autores del "Polizeistaat".

Como «ningún tonto tira piedras a su tejado», según el refranero de mis paisanos, no quisiera seguir transcribiendo otras opiniones del profesor de Niza, resultado del asombro que cree encontrar en

(36) Luciano Parejo Alfonso: La prevalencia del Derecho estatal sobre el regional, Centro de Estudios Constitucionales, Madrid, 1981.

(37) Prosper WeIL: El Derecho administrativo, Cuadernos Taurus, Madrid, 1966, página 17. 
el hecho de que las decisiones del Estado tengan que someterse a las censuras de un Juez: "¿Por qué razón -continúa WEIL- este último, irresponsable, es menos susceptible de equivocación que el hombre que ocupa los lugares de mando y que es responsable de sus actos?» Argumento muy ingenioso, pero que falla en el último extremo, pues, ¿cómo iba a ser responsable de sus actos quien gobernara sin ver sus actos revisados por alguien que no le esté sometido?

Dejando a un lado posturas extremas y remontando la prehistoria del Derecho administrativo, que para algunos se remonta a época bien cercana, considero que el liberalismo político, inspirador del moderno Derecho administrativo, no debe cegarnos hasta el punto de aliarnos ciegamente con uno de los bandos: en nuestro tema con el de los defensores apasionados del autonomismo local. Posturas que van más allá de la ideología, puesto que en la práctica se traducen en interpretaciones restrictivas o extensivas, según el signo de la contienda.

Autonomía local y democracia no son conceptos que conlleven una identificación absoluta, como tan ingenuamente creyó STUART Mill. Esta autonomía hay que fomentarla, favorecerla, pero a la vez que controlarla, con la garantía para todos que representan los Tribunales de Justicia. Y este control tiene que ser tanto más severo cuando se halle en juego una cuestión de competencias entre el Estado y uno de estos Entes locales. Si el Estado ha renunciado al mando y a la jerarquía como principio general en sus relaciones con las Corporaciones locales con el fin de darles «chance» en su autogobierno (selfgovernment), es lógico que el propio ordenamiento cree alguna que otra "arma poderosa en reserva», como la que es objeto del presente estudio, para preservar las competencias que le corresponden como emanación directa de su poder soberano (38). Arma instrumentada como pieza de reemplazo del mando por la fiscalización, a su vez sustituida por el desplazamiento del Ejecutivo por la Jurisdicción (39).

Para terminar este apartado diré que las colisiones competenciales entre Estado y Corporaciones locales surgen principalmente "ratione materiae", pero sin excluir las otras causas, ya que también pueden aparecer por motivos funcionales al existir materias en las

(38) Esta expresión de «arma poderosa en reserva» la recojo de la obra de Bryan KeitHLucas y Peter G. Richards, ya citada, pág. 258, referida a ciertos actos de supervisión por el Estado de actuaciones de las Entidades locales.

(39) Adolf MERKL, en su Teoría general del Derecho administrativo, Editora Nacional, México, 1980, pág. 447. 
que se conserva el nexo jerárquico por vía de recursos entre uno y otras. En cuanto a la competencia "ratione loci», la Administración del Estado no puede utilizar la institución que nos ocupa para resolver cuestiones de competencias interlocales; pero ni Municipios ni Provincias podrán invocar como única causa excluyente de la intervención del Estado la basada en el territorio, ya que, como hemos razonado ut supra, el territorio es elemento común para la actuación simultánea de ambas Administraciones.

$Y$ una última puntualización. La exigencia conjunta de «infracción de las leyes", y que esa infracción afecte "directamente a materias de la competencia del Estado", como causa habilitante y legitimadora de la pretensión de la Administración estatal, de anulación de actos y acuerdos de las Corporaciones locales incursos en estos vicios, impuesta en el artículo $8^{\circ}, 1$, de la Ley 40/1981, de 28 de octubre, tal y como ha sido interpretada por el Real Decreto 1262/ 1981 , de 5 de junio (referido a precepto análogo del Real Decretoley $3 / 1981$, de 16 de enero), no puede verse desvirtuada porque en el artículo $90^{\circ}$ de la propia Ley $40 / 1981$ sólo se haga referencia a "infracción del ordenamiento jurídico", puesto que el propósito del precepto contenido en este artículo $90^{\circ}$ es únicamente el de extender la legitimación para este tipo de recursos, además de a la Administración del Estado, a los miembros de las Corporaciones locales que no hubieran votado los acuerdos favorablemente, siendo éstos los que gozan de una legitimación más amplia, en el sentido de que los fundamentos de sus recursos no tienen por qué circunscribirse al problema competencial, pues, en cuanto al Estado, de existir antinomia entre los artículos $8 .^{\circ}$ y $99^{\circ}$, la misma tendría que resolverse a favor del primero, por ser el específico y el que concreta tales exigencias, ante la imposibilidad de mantener dentro de un mismo texto legal con vigencia a dos preceptos contradictorios.

Antes de cerrar este apartado voy a referirme al proyecto de Ley de Bases de Régimen local, del que sólo tengo noticias a través de la prensa y de lo que ésta recoge de las manifestaciones del portavoz del Gobierno, acompañado en esta ocasión del Ministro de Administración Territorial, sobre lo tratado por el Consejo de Ministros en su sesión del día 5 de octubre de 1983. Ambos se refirieron a que el proyecto tiende a ordenar las competencias estatales o autonómicas (de las Comunidades) que atribuyan en ambos niveles a las Corporaciones locales y fijar las competencias mínimas de éstas no sometidas a tutela. 
Según explicó Tomás DE LA CUADRA — según la prensa-, cuando el Estado o las Comunidades Autónomas entiendan que las Corporaciones locales han violado normas generales, podrán entablar acciones judiciales, pero no administrativas, ni tampoco anular por sí las decisiones de aquéllas. Habrá, sin embargo —-dijo el Ministro-, una excepción: cuando alguna actuación «cause graves daños a los intereses de España», el Gobierno podrá suspenderla de acuerdo con lo establecido por el artículo 155 de la Constitución respecto a las Comunidades Autónomas. Incluso ante la persistencia de tales situaciones se ha previsto llegar a la disolución, dejando a los Entes. locales en manos de una Comisión gestora.

\section{FACILITACIÓN DEL PROCESO}

Los mismos fines que han dado origen a la instauración del proceso especial que nos ocupa, no sólo han servido para su implantación, sino que han justificado las medidas adoptadas para facilitar su viabilidad y realización en la práctica.

Se trata de fines públicos, a cuyo servicio se ponen como instrumentos potestades públicas. Una de ellas es la reglamentada en el' artículo $8 .^{\circ}, 2$, de la Ley 40/1981, reproducción del correlativo del Real Decreto-ley 3/1981, de 16 de enero, en los que se establece que «las Corporaciones locales deberán remitir a la Administración del Estado un extracto de los actos y acuerdos adoptados por las mis-. mas dentro del plazo de seis días siguientes a su adopción».

De no imponerse esta obligación a los Entes locales difícilmente podrían los órganos estatales impugnar sus acuerdos, por graves: que fueran las infracciones por ellos cometidas y sus abusos de poder. De ahí el que se impongan obligaciones, con la finalidad ya dicha, de signo contrario a las medidas adoptadas en el ordenamiento procesal civil, tendentes a eliminar procesos evitables (procesos para evitar el proceso en la terminología de CARNELUTTI).

Con todo, la parquedad del precepto y el gigantismo de la Administración del Estado acentúan la necesidad de un desarrollo normativo por el que quedara debidamente organizado y canalizado. este deber de información. Deber que tendrá que ser extendido en: favor de los órganos de gobierno de las Comunidades Autónomas.

\section{PROCEDIMIENTO PROCESAL}

Aunque esta terminología, en cierta forma sincopada, no sea de uso corriente, yo me atrevo a emplearla impulsado por el mimetis- 
mo que me ofrece el término "procedimiento administrativo", por nadie contestado.

Partiendo de la clara y neta distinción entre proceso y procedimiento, de todos conocida, el procedimiento procesal, por contraste con el administrativo, es aquel que discurre, desde su inicio hasta su final, dentro de un proceso y ante un órgano jurisdiccional. El proceso es, pues, el campo que acota las dimensiones con las que el respectivo procedimiento tiene que ser medido, lo que tiene especial relevancia, sobre todo en sus extremos: en el comienzo y en la terminación.

Respecto a lo primero, puede plantearse el problema, cuando se precisa el recurso de reposición, del momento en que deba considerarse nacida la fase procedimental procesal, dada la ambivalencia de dicho recurso. Problema que en el proceso de que se trata desaparece a radice por la innecesidad de acudir a tal recurso previo, no sólo en el régimen anterior, en el que la doctrina veía en la existencia del acto de suspensión, habilitante de la impugnación del acto suspendido, un motivo exonerador de la reposición, sino en el actual, a pesar de que, como hemos dicho antes, la suspensión es un efecto automático, por ministerio de la ley, de la impugnación del acto $o$ acuerdo sospechoso de ilegalidad, al tratarse de una impugnación en ejercicio de una prerrogativa estatal o de Entidad territorial superior (Comunidad Autónoma) que justifica tal liberación, cualquiera que sea la forma en que la suspensión del acto se produzca.

\section{a) Inicio}

El inicio se producía, en el ordenamiento de nuestra Ley Procesal de 27 de diciembre de 1956 (art. 118), con el traslado del acuerdo de suspensión, lo que debía efectuarse en el brevísimo plazo de tres días. En la actualidad, en cambio, la Administración recurrente deberá sustituir el acuerdo de suspensión por el de impugnación, motivado éste como debía serlo aquél, cuyo traslado será el que abra el contencioso.

El plazo será de seis días hábiles siguientes al de la comunicación del acuerdo, como de forma conteste dispuso el artículo $8 .^{\circ}, 3$, del Real Decreto-ley 3/1981, de 16 de enero, y el artículo $8 .^{\circ}, 3$, de la Ley 40/1981, de 26 de octubre. Ahora bien, ¿cómo deberá entenderse la expresión "comunicación del acuerdo», y, por tanto, cuál será 
el dies a quo de este plazo de seis días? Las dudas nos la resuelve el artículo 5..$^{\circ}$ del Real Decreto 1262/1981, de 5 de junio, al declarar que serán contados "... a partir de la recepción de la correspondiente comunicación". Real Decreto éste que ha sido declarado vigente, repetimos, por el Real Decreto 3183/1981, de 29 de diciembre, con la salvedad que las referencias hechas al Real Decreto-ley $3 /$ 1981 deben entenderse efectuadas a la Ley 40/1981.

Norma que no hay por qué criticar, pues si tanto se elogian las medidas adoptadas en beneficio del principio "favor actionis" cuando éste redunda en provecho de los particulares, qué razón existe para cambiar el tratamiento por el solo hecho de que el favor se extienda a la Administración del Estado, frente a los Entes menores del mismo, si en cualquier caso el designio último no es otro que el de asegurar el imperio de la ley.

Habrá que anotar, por último, que este plazo de seis días puede sufrir una interrupción si dicha Administración del Estado hace uso de la facultad que le concede el número 4 del artículo $80^{\circ}$ de la repetida Ley 40/1981, esto es, la de pedir ampliación de los datos referentes a los actos o acuerdos adoptados, los que por imperativo de este precepto deberán ser suministrados en un término máximo de quince días. Interrupción que servirá tanto para un mejor conocimiento de causa de los problemas existentes en el acuerdo concreto de que se trate, y con ello para una mejor fundamentación del acuerdo de impugnación, como para que a la vista de los nuevos datos las sospechas tenidas por la Administración del Estado en un primer momento desaparezcan, y con las mismas la eventualidad de la impugnación.

Cuando, por el contrario, la impugnación se produzca, ésta arrancará y se basará en el pertinente acuerdo, necesariamente motivado, como ya expusimos, cuyo traslado al Tribunal competente servirá de apertura del procedimiento y de nacimiento del proceso, sin necesidad del escrito de interposición ni del de demanda, como ocurre en el contencioso ordinario.

Singularidad ésta que no debe producirse en el supuesto en que la impugnación se efectúe por los miembros minoritarios de las Corporaciones que votaran en contra de la adopción del acto de que se trate, pues en este caso nos parece correcta la solución propugnada en el anteproyecto ya citado de la Ley de Reforma de la de lo Contencioso, obrante en el Ministerio de Justicia, en el que se establece 
(artículo 117, 2, b) que el procedimiento se iniciará «con la presentación de la demanda", siguiendo el sistema imperante cuando la Administración recurre contra sus propios actos - recurso de lesividad- (art. 57, $1^{\circ}$, de la vigente Ley Jurisdiccional, a contrario sen$s u)$, atendiendo a la razón de que cuando es la propia Administración la que recurre contra sus propios actos, ella es la primera en conocerlos, con lo que desaparece la necesidad del escrito simple de interposición del recurso, concebido para dilatar la formalización de la verdadera demanda, como ha destacado la doctrina científica (40).

Ahora bien, me permito en este punto apuntar que la exigencia de los Tribunales en estos casos de que con la demanda se acompane el expediente completo del acto recurrido en base a la disponibilidad del mismo por la Administración recurrente, deberá ser flexibilizada en los supuestos de que se trata, en cuanto, como miembros disidentes de la Corporación que adoptó el acuerdo, de hecho pueden encontrar entorpecimientos y resistencias para la remisión del expediente al órgano jurisdiccional actuante, debiendo ser éste el que haga los requerimientos necesarios hasta lograr su obtención.

\section{b) Tramitación}

Una vez iniciado el proceso, se entra en la tramitación del procedimiento regulado en el artículo 118 de la Ley Jurisdiccional, con normas específicas, diferenciadoras de las establecidas para el proceso común u ordinario; normas a las que se remite, reafirmando su vigencia, el artículo $8^{\circ}, 1$, de la tan repetida Ley 40/1981, de 28 de octubre. Tramitación que comprende la reclamación del expediente administrativo, la publicación de anuncios, el emplazamiento y personación de las partes, las alegaciones de la Corporación local interesada, el informe de la Abogacía del Estado y las alegaciones de cuantos se hubieran personado en el proceso. Sin que esté prevista una fase probatoria.

\section{c) Sentencia}

Refiriéndose a ésta, el artículo $8 .^{\circ}, 1$, en su parte final, de la Ley $40 / 1981$, establece que el fallo contendrá alguno de los pronunciamientos a que se refieren los artículos 81 y siguientes de la Ley

(40) Aurelio Guaita: El proceso administrativo de lesividad, Ed. Bosch, Barcelona, 1953, págs. 147-150. 
de la Jurisdicción; reformando en este sentido la forma en que se trataba este particular en el número 5 del artículo 118 antes citado.

d) Recursos

Continúa en vigor el precepto contenido en el número 6 de este artículo $118 \mathrm{y}$, por tanto, la posibilidad de que contra la sentencia de la Sala de la Audiencia puedan interponer recurso de apelación cuantos hubieran comparecido en primera instancia. 


\section{REVISTA DE ADMINISTRACION PUBLICA}

\section{CONSEJO DE REDACCION}

Manuel Alonso Olea - José María Boquera Oliver - Antonio Carro Martínez - Manuel F. Clavero Arévalo - Rafael Entrena Cuesta - Tomás Ramón Fernández Rodríguez Fernando Garrido falla - Jesús González Pérez - Ramón Martín Mateo - Lorenzo Martín-Retortillo Baquer - Sebastián Martín-Retortillo Baquer - Alejandro NiEto José Ramón Parada VÁzouez - Manuel Pérez Olea - Fernando Sainz de Bujanda - Juan Santamaría Pastor - José luis Villar Palasí

SUMARIO DEL NUM. 103 (enero-abril 1984)

In Memoriam: Luis Jordana de Pozas $(t)$, por E. García DE ENTERría.

\section{ESTUDIOS:}

- A. Cano Mata: «Ejecución judicial de sentencias contencioso-administrativas. El embargo a la Administración como manifestación del principio de tutela judicial efectiva».

- J. M. Serrano Alberca: «La protección de las libertades públicas del militar».

- J. PEMÁN Gavín: "Hacia un Estatuto del enfermo hospitalizado».

- J. Aguilar Fernández-Hontoria: "Veinticinco años de la revisión de oficio de las disposiciones reglamentarias: un análisis prospectivo».

- J. M. " García Marín: "El dilema ciencia-experiencia en la selección del oficial público en la España de los Austrias».

- I. Borrajo InIEsta: «Indemnización constitucional: a propósito de la sentencia de Bivens del Tribunal Supremo de los Estados Unidos».

\section{JURISPRUDENCIA:}

I. Comentarios monográficos:

- J. González PÉrez: «Indemnización al contratista en los supuestos de resolución del contrato por suspensión temporal de las obras por plazo superior a un año».

- J. TOledo JÁudenes: «El fin de la reformatio in peius en la vía económico-administrativa».

- E. Ruiz-Jarabo Ferrán: «Comentario a la sentencia dictada por el TC sobre la pensión de viudedad del régimen agrario».

II. Notas:

Contencioso-administrativo:

- A) En general (J. Tornos Mas y T. Font I Llovet).

- B) Personal (R. Entrena Cuesta).

CRONICA ADMINISTRATIVA

BIBLIOGRAFIA

Suscripcion anual:

PRECIOS DE 1984

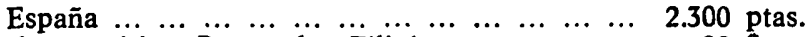

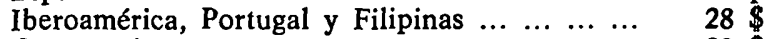

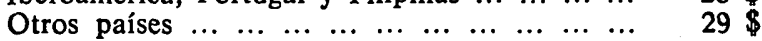

Número suelto:

$\begin{array}{llllllllllllll}\text { España } & \ldots & \ldots & \ldots & \ldots & \ldots & \ldots & \ldots & \ldots & \ldots & \ldots & \ldots & \ldots & 950 \text { ptas. }\end{array}$

$\begin{array}{lllllllllllllll}\text { Extranjero } & \ldots & \ldots & \ldots & \ldots & \ldots & \ldots & \ldots & \ldots & \ldots & \ldots & \ldots & 11 \$\end{array}$

CENTRO DE ESTUDIOS CONSTITUCIONALES

Pedidos: Plaza de la Marina Española, 9

REVL-1984 núm. 222. MARTIN DEL BURGO Y MARCHANAD, ANGEL. Maña) GNACION Y SUSPENSION... 
REVL-1984, núm. 222. MARTIN DEL BURGO Y MARCHAN, ANGEL. IMPUGNACION Y SUSPENSION... REVL-1984, núm. 222. MARTIN DEL BURGO Y MARCHAN, ANGEL. IMPUGNACION Y SUSPENSION... 